\title{
Islamic Banking: Modern Trends and Problems
}

\author{
Jusupova Liliya Mirgaziyanovna \\ Department of Securities, Stock Exchange and Insurance \\ Kazan Federal University \\ Kazan, Russian Federation \\ e-mail address: lili2407@list.ru
}

\author{
Kokh Igor Anatolyevich \\ Department of Securities, Stock Exchange and Insurance \\ Kazan Federal University \\ Kazan, Russian Federation \\ e-mail address: koch-mail@yandex.ru
}

\author{
Nikonova Tatyana Viktorovna \\ Department of Securities, Stock Exchange and Insurance \\ Kazan Federal University \\ Kazan, Russian Federation \\ e-mail address: viktta@mail.ru
}

\begin{abstract}
Islamic Finance is a financial system based on Islamic principles of transactions, offering alternatives to traditional forms of ethical and social financial behavior. Islamic banks started a rapid growth after the global financial crisis of 2008, showing greater resilience to risk than traditional banking institutions. Islamic banking is a normative concept that can be defined as banking compatible with the system of Islamic values. Today there are more than 300 Islamic banks in the world. Despite the significant growth observed in the assets of Islamic banks, their share in the global financial market is relatively small.
\end{abstract}

A significant trend is the active penetration of Islamic banks into the national economies of the developed and developing countries, especially in the economies of countries that are seriously underfunded. The article describes the main trends, as well as the problems that prevent the expansion of Islamic banking in the modern economy. The authors conclude that Islamic banking faces such restrictions and limitations as: not relevant national banking legislation, lack of necessary financial infrastructure, low level of individual and corporative financial literacy, lack of information about Islamic financial products.

Keywords - islamic banking, islamic financial institutions, islamic windows, islamic finance

\section{INTRODUCTION}

Islamic banking is now accepted to consider regardless of geographical reference to Islamic States, it is already a General economic phenomenon with its own principles of transactions and investment. The main distinctive feature of Islamic banking is the implementation of any activities in strict adherence to the principles of Islam [1].

The formation of Islamic financial institutions and instruments has begun in the 1960-1970-s, when Islamic banks appeared in several Middle East countries and Malaysia and international Islamic Development Bank was established [2].
There is an opinion that promotion of Islamic financial institutes and instruments in non-Moslem countries is a result of oil crisis of the 70s of the XX century, when, against the background of oil price growth, rich countries of Persian Gulf states extend their influence geography [3].

Islamic banks perform the same functions as traditional banks, since they, like traditional banks, accumulate temporarily unused funds from their clients and provide them for temporary use, mediate payments and settlements for commercial organizations and individuals [4].

The key point distinguishing Islamic banks from traditional ones is that they do not use fixed interest instruments (loans as well as deposits). Islam does not condemn the very fact of gaining any profit from financial transactions, but it prohibits a fixed income that does not depend of the project or business outcome.

This means that the remuneration to the owner of capital should not be guaranteed regardless of the performance of the borrower, as it happens in the case of payment of traditional bank interest.

An Islamic bank may earn some profit only if it is a partner in the borrower's project or business and it shares profit or loss completely.

\section{ISLAMIC BANKS' DEVELOPMENT TRENDS IN THE GLOBAL ECONOMY}

It should be recognized that the principles of Islamic banks do not contradict the principles of the market economy, and rejecting fixed interest, Islamic banks do not work on a charitable basis [5].

The list of vital requirements and prohibitions of Sharia concerning financial operations may be presented as follows:

1. Charging loan interest that is established as a fixed percent of the loan amount is prohibited. 
2. Contracts / agreements in which partners' (either one or both) obligations depend on uncertainty or coincidence is prohibited.

3. Multiple reselling of financial instruments with no relevant information reason is prohibited.

4. Transferring risk connected to financial instruments to the partner is prohibited. Financial institutions should share the risks with their clients.

5. The remuneration for lending or funding without taking on the risk is prohibited.

6. Fines and penalties for late repayment of funding are prohibited

7. Selling of goods, services, financial instruments and other assets is prohibited if the seller does not own these assets.

8. Reselling of debt at a price other than the face value of this debt is prohibited.

9. Selling one debt obligation for another debt obligation is prohibited.

10. Debt financing may only be used to create new nonfinancial assets.

11. Only physically existing assets may be the basic asset for Islamic financial products and services.

12. Only halal business may be funded. Funding projects and corporations related to alcohol, tobacco, pork, gambling, etc. are prohibited.

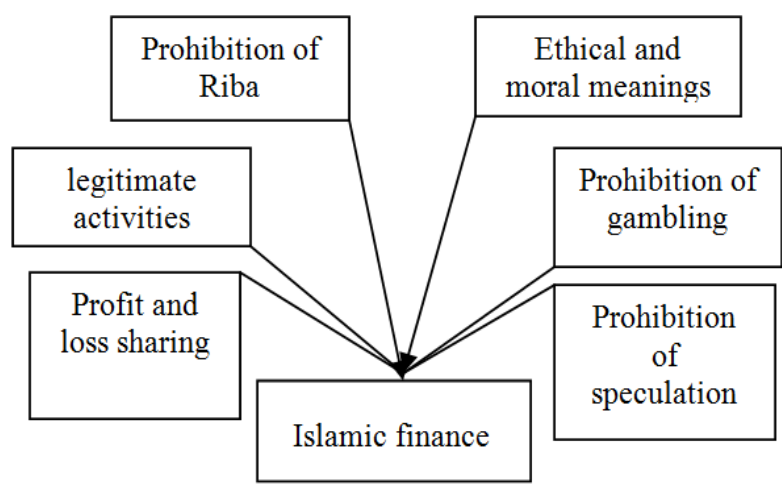

Fig. 1. Basic principles of Islamic finance

Today, Islamic banks offer a wide range of financial products and services. Major types of these products and services are:

- mudaraba and musharaka - banking products based on the principles of partnership in particular project or business including sharing of any profit or loss;

- murabaha, ijara (leasing), salam - banking products based on bank's participation in particular deal with nonfinancial goods or assets;

- vakala (letter of credit) - banking product based on bank's payable mediation in money transfer operations.
Islamic banks started a rapid growth after the global financial crisis of 2008 [6, 7]. This crisis followed by global economic depression raised a number of questions about the role of banks in the incident and forced various stakeholders to seek solutions to such financial failures [8].

Islamic banks showed greater resilience to risk than traditional banking institutions; in particular, they are better capitalized and have better asset quality and risk-taking capacity [9-11].

Over the years, Islamic financial institutions have expanded their geographic reach and increased their size. In the middle 1990-s, Islamic banks' assets totaled $\$ 150 \mathrm{bln}$; till 2017 they raised up to $\$ 1,5 \mathrm{tln}$. (Fig.2).

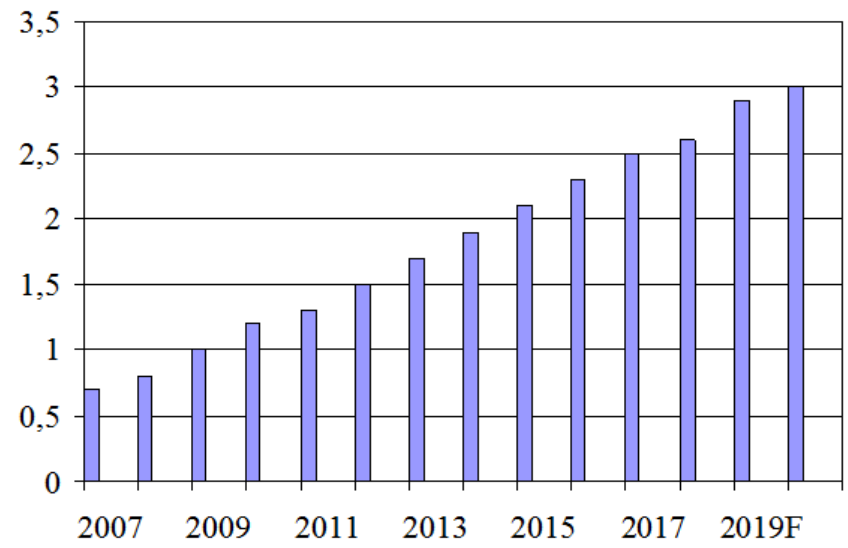

Fig. 2. Expected islamic assets globally [12]

Today the share of Islamic financial system is about $1 \%$ of the world's total. The major sector is Islamic banking [12].

It should be noted that the average annual growth rate of assets of Islamic banks in recent years has slowed slightly [13].

This is due to, among other reasons, the devaluation of the most of emerging markets' currencies, the slowdown in global product growth, the prolonged period of decline in energy prices, as well as certain mistrust of investors and consumers in the banking sector caused by the crisis. Despite the fact that the industry is growing, its profitability is still lagging behind similar traditional banking institutions.

Currently, there are more than 300 Islamic banks in the world. In Europe first Islamic banks appeared in the 1970-s, e.g. in Luxembourg in 1978 Islamic Banking System (now Islamic Finance Bank) was established in Switzerland in 1981 - Dar al-Mal al-Islami (now - Faisal Private Bank) owned by Ithmaar Bank, Bahrain [14].

The most important Islamic Finance center in Europe is London, where six Islamic banks are operating now. The expansion of Islamic banking services by some of the largest banks of the West (e.g. Goldman Sachs, Citibank, Deutsche Bank, BNP Paribas) is also observed. The above-mentioned banks opened «Islamic windows» as they tried to reach new market segments with their financial services. 
It can be assumed that the expansion of the activities of Islamic financial institutions in non-Islamic countries is inspired by the needs of a significant number of Muslims living in these countries [15].

At the same time, it should be emphasized that despite the increase in the assets of Islamic banks, their share in the economy of most Islamic countries cannot be called significant. For example, their ratio in comparison with the assets of traditional banks is $49 \%$ in Saudi Arabia, 39\% - in Kuwait, 33\% - in Yemen, 26\% - in Qatar, less than 10\% - in Bahrain, Jordan and Pakistan [16].

Only in two Islamic countries (Sudan and Iran) the share of Islamic banking in the banking system is above 50\% (Fig.3) [17].

It should also be recognized that the majority of Islamic banks are small ones. Only $11 \%$ of Islamic banks have total assets of more than $\$ 20$ billion, $11 \%$ - \$10-20 billion, $12 \%-$ \$ 5-10 billion, $27 \%-\$ 1-5$ billion and the rest $40 \%$ have less than $\$ 1$ billion in assets [18].

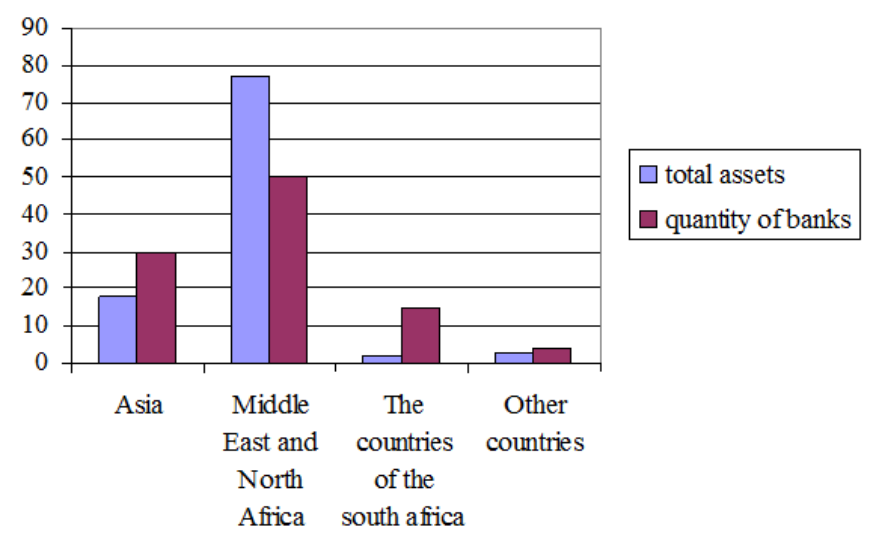

Fig. 3. The regional structure of assets and the number of Islamic banks [18]

As we mentioned above, the profitability of Islamic banks is lower than that of traditional banks. Moreover, it is uneven, as Islamic banks in Asian, African and Gulf countries demonstrate relatively higher profitability $[19,20]$.

Many post-Soviet countries also have the opportunity to develop Islamic finance institutions in their regions.

As for the CIS countries, Kazakhstan was the first to introduce legal acts on Islamic financial instruments and institutions: the law regulating Islamic banks and Islamic financing was passed in 2009. Currently, Islamic banking in Kazakhstan is less than $1 \%$ of the total assets of the banking sector.

By 2020, Kazakhstan aims to bring the Islamic banking industry to $3-5 \%$ of total banking assets. To achieve this goal, the country has already developed strict plans [21]. But till now Islamic sector of Kazakhstan's bank system is presented only by Al Hilal Islamic Bank established in 2010.

Kyrgyzstan has adopted 16 normative acts regulating Islamic banking. JSC "EcoIslamicBank" is operating on the principles of Islam since 2008. Nevertheless till now the population of Kyrgyzstan demonstrates a low level of demand for Islamic banking services. We believe it is the result of a low level of financial culture.

Similar problems of financial culture are observed in Azerbaijan too. Although Azerbaijan is one of the CIS countries that creates a relatively friendly framework for Sharia-based banks, Islamic banks are represented here only by separate branches.

Islamic banking operations are conducted only within limits of standard banking regulations. In 2015, the Islamic Development Bank (IDB) allocated a grant of \$200,000 to Azerbaijan to improve the legislation, which is to become the basis for Islamic banking.

In Russia, the first attempts to introduce Islamic banking date back to 1997; most of them did not succeed. The first Islamic bank in Russia was Badr-Forte in Moscow. It has got banking license in 1991 and was offering Islamic financial instruments and services since 1997.

In December, 2006 its license was cancelled by Bank of Russia because of repeatedly violation of banking rules and regulations. In 2016 there was only one bank with "Islamic window" service in Russia - Tatfondbank (Kazan), which had also lost its license in 2017 because of multiple violation of banking rules.

For the Russian financial system, the growth of Islamic banking makes it possible to increase the volume of incoming foreign investments, but it is necessary to develop attractive proposals for potential investors. Currently, the development of Islamic finance in Russia is hindered by the absence of special legislation, legal conflicts, and ambiguity in tax regulation [22].

As an example of such conflicts we can mention the fact that according the civil code and federal banking law, the contract between the banks and the borrowers or depositors should assume only fixed interest payments.

This means Islamic banking is illegal according to Russian legislation. Nevertheless the Islamic Development Bank approved funding of 29 projects in Russia (totally \$7.4 million) in 2017. Islamic University in Moscow, Islamic University in Kazan, Islamic Institute and Polyclinic in Saratov and Islamic Institutes in Dagestan are among these projects.

\section{PROBLEMS OF ISLAMIC BANKING DEVELOPMENT IN THE GLOBAL ECONOMY}

According to the report on the competitiveness of Islamic banks in the international banking system, the world will see an increase in Islamic assets, and this growth will be associated with countries where Islamic finance has already been sufficiently developed (Fig.4). 


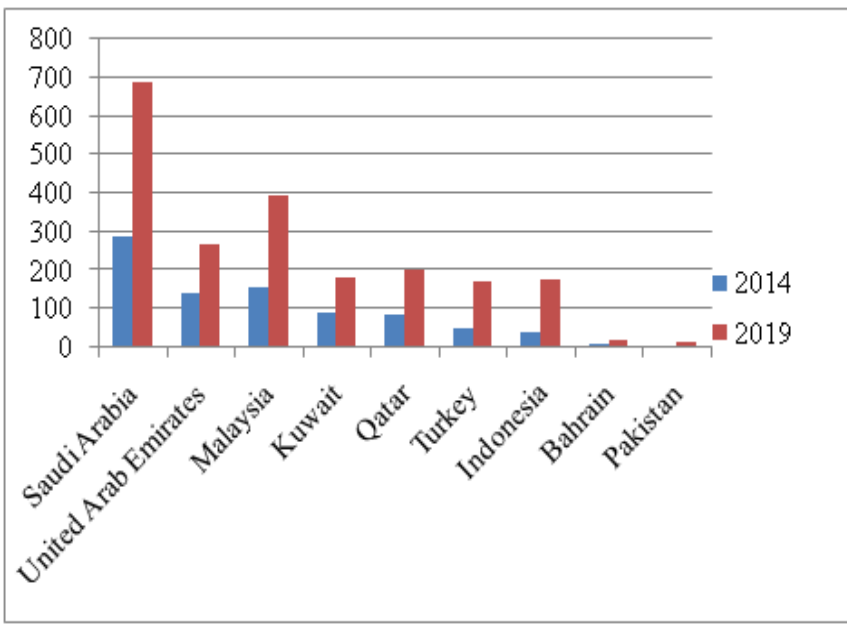

Fig. 4. Islamic Banks’ Assets, \$ bln. [23]

The active penetration of Islamic banks into the economic sphere of the developed and developing world, especially in the economies of countries experiencing serious funding shortages, can be identified as a significant trend [24].

There are regular attempts to build an Islamic finance industry in the world, but the list of contentious and frankly unclear points is still extensive.

As a result, there is a contradiction: business and government are working on the implementation of Islamic banking practice, while it is not really complete and fullfledged model today.

The results of our research allow us to formulate a number of problems that impede the expansion of Islamic banking.

First, there is a lack of regulation and a lack of certainty about the status of Islamic banks in the legal framework of non-Muslim States. Legal problems are associated with significant differences between Islamic and traditional banking, the principles and methods that are typical for banking operations.[25] Since Islamic banking is characterized by compliance with Sharia requirements, European clients are likely to prefer the traditional banking services. In addition, in different countries the interpretation of religious rules varies, so there are some differences with regard to the rules of Sharia compliance between different regions.

Second, the difficulties of expanding investment activities in the credit markets of non-Muslim, first of all industrialized, countries are associated with serious interbank competition, especially from transnational banks that have formed strong competitive advantages. Islamic banks are often small and are not able to use the potential of the traditional economy; few of them are highly competitive.

Third, the provision and using of financial services and products consistent with Islamic religious principles in nonMuslim countries pose particular challenges, including identification, measurement, monitoring and control of the underlying risks. Effective risk management in Islamic banks is particularly important because it is more difficult for them than for traditional banks to cope with the challenges of globalization.

Fourth, banking technology is another challenge, as Islamic banks have to compete in a highly technological banking market that uses a wide range of sophisticated banking products. The problem is not only in the adoption of technologies, but also in the preparation of a suitable environment that will allow them to use technology to compete effectively, to offer innovative banking products. Meanwhile, Islamic banks are less mobile than traditional banks.

\section{CONCLUSION}

Islamic banking and Islamic finance have certain undeniable prospects in a developed economy along with traditional banks.

However, despite the increased interest, the penetration of Islamic banking in non-Muslim countries is quite difficult, because Islamic banks are difficult to expand in different jurisdictions and face regulatory and religious contradictions in terms of approvals.

Progress in adapting Islamic banking is still uneven in different countries of the world.

We believe not only Islamic banks but also regulators in CIS countries should inform market participants about the principles and mechanisms of Islamic finance and provide educational support for Islamic financial institutions.

It should be recognized that Kazakhstan has the highest chances of promoting Islamic banks if compared with any other CIS country.

In general, when constructing interrelations in the sphere of Islamic financial products in the post-Soviet countries, it is necessary to take into account that Islamic banking is intended not only to attract foreign capital. First of all, these are fullfledged economic mechanisms that allow people to participate in the development of the national economy, and, accordingly, rules of the game are set for these people.

One of the most important directions of modern banking development is Islamic banking including "Islamic windows". Regulators and lawmakers should pay special attention to this segment, as Islamic financial instruments and institutions are increasingly innovative, flexible in times of crisis and able to generate high, safe and stable income for their clients.

The analysis shows that in recent years this segment has faced a lot of unsolved problems. The major one is the lack of regulation and the lack of certainty of the status of Islamic banks in the legal field of non-Muslim States. That is why governments are the main institutions on whose actions the further functioning of Islamic banking depends. 


\section{Acknowledgment}

The authors express their gratitude to the scientific department of Kazan Federal University for the help and support in the publication of materials.

\section{References}

[1] A. Mabid, "An economic theory of Islamic finance", ISRA International Journal of Islamic Finance, Vol. 9-2, pp. 117-132, 2017.

[2] S.N.H. Naqvi, "Islamic economic system: fundamental issues", Islamic Studies (Islamabad), Vol. 16 No. 4, 1977.

[3] I.Sobol, "Islamic Banking in the European Union", Countries European Integration Studies. No 9 pp. 184-197, 2015.

[4] N. Trada, M. Trabelsib, J. Goux, "Risk and profitability of Islamic banks: A religious deception or an alternative solution?" European Research on Management and Business Economics, vol. 23, Issue 1, January-April 2017, pp. 40-45.

[5] M.S. Aliskerov, "Islamic banking in Egypt at the present-day stage of the country's financial development", Problems of modern economics, vol. 3, pp. 243-247, 2017

[6] E.S. Biryukov, "New tendencies in the activity of Islamic banks (on the example of the Arabian monarchies)", World economy and international relations, vol. 7, pp. 3-13, 2008.

[7] K. Bourkhis,M.S. Nabi, "Islamic and conventional banks' soundness during the 2007-2008 financial crisis", Review of Financial Economics, 22, pp. 68-77, 2013

[8] M. Masih, "Islamic Finance and Banking", Journal Emerging Markets Finance and Trade, vol. 53, pp. 1455-1457, 2017

[9] N. Isik, "Growth, Islamic Banking And Schumpeterian Vision: An Empırıcal Evidence From The Gulf Arab States", International Journal of Islamic Economics and Finance Studies, vol 4, No 1, pp. 40-51, 2018.

[10] M.A. Trabelsi, "The impact of the financial crisis on the global economy: Can the Islamic financial system help?" Journal of Risk Finance, vol. 12, pp. 15-25, 2011.

[11] F. Jawadi, N. Jawadi, W., "LouhichiConventional and Islamic stock price performance: An empirical investigation", International Economics, vol. 137, pp. 73-87, 2014

[12] M.A. Chapanova, "Islamic finance: perspective limitations", News. Economy. Retrieved from: http://www.vestifinance.ru/articles/93401
[13] Y.C. Pratama, "The Impacts of Globalization on Inflation and Transmission of Islamic Monetary Policy: Case Study in Indonesia", Journal of Islamic Banking and Finance, vol 5, No 2, pp. 19-29, 2017.

[14] E.A. Ryzhkova, "Muslim finance in the system of public finance of the countries of the Arab East", 25 years of foreign policy of Russia. Collection of materials X of the Convention of RAMI: 2017, pp. 392 403.

[15] T.V. Nikonova, I.A. Kokh, L.M. Safina, "Principles and Instruments of Islamic Financial Institutions", Procedia Economics and Finance, vol. 24. pp. 479-484, 2015.

[16] S.A. Shaikh, "Economic Analysis of Islamic Banking in Pakistan", Journal of Muamalat and Islamic Finance Research, vol 10, No.1, 2013, pp. 69-90.

[17] Islamic Financial Services Industry Stability Report 2016. Kuala Lumpur: Islamic Financial Services Board, 2016.

[18] T.V. Nikonova, L.M. Yusupova, F.S. Nugaev, "Islamic Financia Institutions in the European Economy", Journal of Economics and Economic Education Research, vol. 17, pp. 144-149, 2016.

[19] M. Ariff, M. Bader, M. Shamsher, T. Hassan "Cost, revenue, and profit efficiency of Islamic versus conventional banks: International evidence using data envelopment analysis", Islamic Economic Studies, vol. 15, pp. 23-76, 2008

[20] E. Beck, A. Demirgüç-Kunt, O. Merrouche "Islamic vs conventional banking: Business model, efficiency and stability" Journal of Banking \& $\begin{array}{lllll}\text { Finance, } & \text { vol. } & 37 & \text { pp. } & 433-447,\end{array}$ http://dx.doi.org/10.1155/2016/7893961

[21] A New Frontier for Islamic Finance. Kazakhstan Islamic Finance 2016 Almaty: Mutual Insurance Society "Takaful" Halal Insurance». 2016, 138 PP.Z.M.

[22] Gafarov, K.Yu. Kurilov, "Research application of islamic banking in Russia", Sustainable development of science and education, vol. 1. pp. 15-22, 2016.

[23] M. Fakhfekh, N. Hachicha, F. Jawadi, N. Selmi, A. Cheffou Idi, "Measuring volatility persistence for conventional and Islamic banks: An FI-EGARCH approach", Emerging Markets Review, vol. 27, pp. 84-99, 2016.

[24] S.Z. Farook, M.O. Farooq, "Incentive based regulation for Islamic banks", Journal of Islamic Accounting and Business Research, vol. 2 Issue: 1, pp. 8-21, 2011

[25] T. Cham, "Determinants of Islamic banking growth: an empirical analysis", International Journal of Islamic and Middle Eastern Finance and Management, Vol. 11 Issue: 1, pp.18-39, 2018. doi.org/10.1108/IMEFM-01-2017-0023 